\title{
Pengaruh Kualitas Produk dan Citra Merek Terhadap Penetrasi Pasar Industri Kecil Menengah Klaster Batik Di Kota Semarang
}

\author{
Findri Mustika Sari ${ }^{1{ }^{* *}} \&$ Saryadi $^{2}$ \\ ${ }^{1,2}$ Departemen Administrasi Bisnis, Fakultas Ilmu Sosial dan Ilmu Politik, Universitas Diponegoro \\ *E-mail: findrims@gmail.com
}

\begin{abstract}
The problem faced by IKM batik in Semarang City is the weakness of penetration ability of Batik Semarangan style in Semarang City. This can be seen from the low market share in Semarang City, even showing a declining trend from 2012 to 2016. The perceived factor is able to influence the penetration of IKM Batik Semarang market, among others are product quality and brand image. This study was conducted to determine the effect of product quality and brand image on market penetration of Small and Medium Industry (IKM) Batik in Semarang City. In this study using sampling technique sampling census so that can be taken 74 craftsmen Klaster Batik members in the city of Semarang. The data analysis used is regression. The results showed that product quality (X1) has a positive and significant influence on market penetration $(Y)$, brand image (X2) has a positive and significant influence on market penetration (Y). The results also show that there is a positive and significant influence between product quality and brand image together to market penetration.
\end{abstract}

\begin{abstract}
Abstraksi Permasalahan yang dihadapi oleh IKM batik di Kota Semarang adalah lemahnya kemampuan penetrasi corak Batik Semarangan di Kota Semarang. Hal ini dapat terlihat dari rendahnya market share di Kota Semarang, bahkan menunjukkan kecenderungan yang semakin menurun dari tahun 2012 sampai 2016. Faktor yang dirasakan mampu mempengaruhi penetrasi pasar IKM Batik Semarang antara lain adalah kualitas produk dan citra merek. Penelitian ini dilakukan untuk mengetahui pengaruh kualitas produk dan citra merek terhadap penetrasi pasar Industri Kecil dan Menengah (IKM) Batik di Kota Semarang. Dalam penelitian ini menggunakan teknik pengambilan sampel sensus sampling sehingga dapat diambil 74 perajin anggota Klaster Batik di Kota Semarang. Analisis data yang digunakan adalah regresi. Hasil penelitian menunjukkan bahwa kualitas produk $\left(\mathrm{X}_{1}\right)$ mempunyai pengaruh positif dan signifikan terhadap penetrasi pasar $(\mathrm{Y})$, citra merek $\left(\mathrm{X}_{2}\right)$ mempunyai pengaruh positif dan signifikan terhadap penetrasi pasar (Y). Hasil penelitian juga menunjukkan bahwa ada pengaruh positif dan signifikan antara kualitas produk dan citra merek secara bersama-sama terhadap penetrasi pasar.
\end{abstract}

Keywords: Brand Image, Product Quality, Market Penetration

\section{Pendahuluan}

Dalam era globalisasi, persaingan bisnis menjadi sangat tajam, baik di pasar domestik maupun di pasar global. Perusahaan dihadapkan pada berbagai peluang dan ancaman, baik yang berasal dari luar maupun dari dalam negeri. Saat ini perdagangan internasional lebih mengarah pada liberalisasi perdagangan dimana hambatan-hambatan tarif maupun non tarif menjadi semakin berkurang. Bagi perusahaan yang memiliki daya saing dan efisiensi produk yang tinggi, liberaliasi perdagangan merupakan peluang yang besar untuk memenangkan persaingan di tingkat global, sebaliknya bagi perusahaan yang memiliki daya saing dan efisiensi produk yang rendah hal ini merupakan ancaman bagi kelangsungan usaha mereka.

Pada Industri Kecil dan Menengah, selanjutnya disebut dengan IKM, liberalisasi perdagangan berimplikasi cukup signifikan, yakni munculnya tuntutan untuk melakukan proses produksi dengan efektif dan efisien, serta dapat menghasilkan produk yang sesuai dengan permintaan pasar. Kondisi IKM secara umum di Kota Semarang memperlihatkan bahwa setiap tahun produk IKM Semarang mengalami pertumbuhan dan perkembangan baik pada jenis, desain maupun bahan baku, yang tercipta dari kreativitas dan inovasi para pelaku usaha di Semarang, Jawa Tengah. Pertumbuhan dan perkembangan hasil IKM 
tersebut dapat dilihat dari keanekaragaman produk IKM yang diluncurkan perusahaan untuk dapat mempertahankan eksistensinya dalam dunia usaha dan meningkatkan daya saingnya.

Salah satu upaya perusahaan untuk meningkatkan kinerja dan daya saingnya adalah dengan meningkatkan penetrasi pasar. Penetrasi pasar berarti mencoba menjual lebih banyak produk yang tersedia di pasar yang ada (Ennew \& Waite, 2007). Strategi penetrasi pasar diartikan sebagai strategi yang berhubungan dengan kedalaman penjualan produk tertentu di pasar tertentu. Perusahaan yang memiliki penetrasi pasar yang baik akan dapat melakukan penjualan produknya secara lebih mudah, mengambil perajin batik dari berbagai macam demografi sekaligus meningkatkan omset dan keuntungannya.

Salah satu bentuk IKM yang sedang bertumbuh di Kota Semarang adalah Batik Semarangan yang saat ini berjumlah 74 pengusaha (Laporan Disperidag Semarang, 2017). Kebangkitan batik di Kota Semarang dimulai tahun 2012 melalui program pencarian perajin batik dari generasi muda yang ada untuk dibina secara teknis dasar cara pembuatan, gambar, pewarnaan, pencelupan warna natural/alam. Permasalahan dengan IKM Batik di Semarang ini adalah batik Semarang kurang dikenal dan diminati oleh perajin batik (Nurainun dan Rasyimah, 2008). Padahal corak dan motif batik Semarang cukup unik. Menurut Ketua Umum Asosiasi Perancang dan Pengusaha Mode Indonesia (APPMI), Taruna Kusmayadi, corak dan motif yang terdapat pada Batik Semarang cukup unik dan tidak kalah dengan batik-batik yang sudah popular (Dewi, 2008).

Perbedaan perajin batik Semarang dengan perajin di daerah lain adalah mereka tidak pernah membakukan motif. Sebagai masyarakat pesisir Utara Jawa, mereka pada umumnya membatik dengan motif naturalis. Seperti binatang, alam, rumah dan lain sebagainya. Hal ini berbeda dengan batik Solo dan Jogja yang mempunyai pakem dari kraton. Selain itu, perbedaan tersebut disebabkan oleh letak geografis daerah pembuat batik yang bersangkutan, sifat dan tata penghidupan daerah yang bersangkutan, kepercayaan dan adat daerah yang bersangkutan, keadaan alam sekitarnya dan kontak atau hubungan dengan sentra batik lain (Djoemena, 1986). Saat ini, IKM Batik Semarangan mengalami ketertinggalan dari industri batik kota lain di Jawa Tengah seperti Solo, Pekalongan, maupun Rembang (Lasem) dalam koridor apresiasi terhadap kearifan budaya lokal. Daerah-daerah tersebut telah mengakomodir dan menunjang sisi unik produk lokalnya, sehingga masyarakat umum mengenal produk yang bermotif dengan asal daerah mereka, seperti Batik Solo, Batik Pekalongan, Batik Lasem, dan Batik Cirebon dan mampu berekspansi ke kota lain seperti Semarang.

Ketatnya persaingan batik di Kota Semarang juga diakibatkan oleh semakin banyaknya corak batik yang dijual di Kota Semarang. Saat ini, upaya untuk memperebutkan perajin batik tidak lagi terbatas pada atribut fungsional produk seperti kegunaan suatu produk, melainkan sudah dikaitkan dengan corak dan merek yang mampu memberikan citra terhadap suatu produk. Menurut Kotler dan Keller (2008), corak menunjukkan ciri khas, dimana hakikatnya untuk segala jenis produk (barang, jasa, pengecer, bisnis online, orang, organisasi, tempat dan gagasan) yaitu dengan cara memberikan nama pada produk dan menyertakan makna atau arti khusus menyangkut apa yang ditawarkan produk bersangkutan dan apa yang membedakannya dari produk-produk pesaing. Suatu merek bukan hanya sekedar nama atau pembeda antara suatu produk dengan produk yang lain tetapi lebih dari itu merek mampu memberikan asosiasi tertentu dalam benak perajin batiknya. Begitu banyak perusahaan dengan hasil produksinya beberapa produk yang dijual di pasar tentunya harus dibedakan dengan pesaing, oleh karena itu produk tersebut harus diberi tanda, simbol atau desain yang mengidentifikasi dan mendiferensiasi dengan produk lain untuk melakukan penetrasi pasar secara efektif.

Perumusan masalah dalam penelitian ini adalah: (1) Bagaimana pengaruh kualitas produk terhadap penetrasi pasar pada Industri Kecil dan Menengah (IKM) Batik di Kota 
Semarang?; (2) Bagaimana pengaruh citra merek terhadap penetrasi pasar pada Industri Kecil dan Menengah (IKM) Batik di Kota Semarang?; (3) Bagaimana pengaruh kualitas produk dan citra merek terhadap penetrasi pasar Industri Kecil dan Menengah (IKM) Batik di Kota Semarang?.

Tujuan penelitian ini adalah: (1) Untuk mengetahui pengaruh kualitas produk terhadap penetrasi pasar pada Industri Kecil dan Menengah (IKM) Klaster Batik di Kota Semarang; (2) Untuk mengetahui pengaruh citra merek terhadap penetrasi pasar padaIndustri Kecil dan Menengah (IKM) Klaster Batik di Kota Semarang; (3) Untuk mengetahui pengaruh kualitas produk dan citra merek terhadap penetrasi pasar Industri Kecil dan Menengah (IKM) Batik di Kota Semarang.

\section{Kajian Teori}

Kualitas produk adalah keseluruhan ciri serta sifat dari suatu produk yang berpengaruh pada kemampuan untuk memuaskan kebutuhan yang dinyatakan atau tersirat (Kotler, 2009). Kualitas produk juga didefinisikan sebagai suatu kondisi dinamis yang berhubungan dengan barang, jasa, manusia, produk, dan lingkungan yang memenuhi atau melebihi harapan (Goetsch \& Davis, 2002). Pelanggan yang merasa puas akan kembali membeli, dan mereka akan memberi tahu yang lain tentang pengalaman baik mereka dengan produk tersebut. Perusahaan yang pintar bermaksud untuk memuaskan pelanggan dengan hanya menjanjikan apa yang dapat mereka berikan, kemudian memberikan lebih banyak dari yang mereka janjikan (Juran, 2003).

Branding dapat digunakan sebagai suatu istilah namun untuk memperjelas pemberian nama merek, citra merek ataupun trade mark untuk suatu produk. Seperti yang dikemukakan oleh Stanton, pentingnya merek bagi perajin batik adalah dengan adanya merek ini maka akan memudahkan bagi perajin batik untuk membedakan produk / jasa yang dihasilkan perusahaan. Merek juga memberikan jaminan akan kestabilan kualitas yang berarti bahwa suatu produk dengan merek yang sama maka kualitasnya pun akan sama walaupun dibeli dimana saja.

Penetrasi pasar berarti mencoba menjual lebih banyak produk yang tersedia di pasar yang ada (Ennew dan Waite, 2007).Bagi sebagian pemasar, strategi penetrasi pasar (market penetration strategy) diartikan sebagai strategi yang berhubungan dengan kedalaman penjualan produk tertentu di pasar tertentu. Strategi penetrasi pasar merupakan salah satu jenis strategi intensif dan disebut juga sebagai strategi pertumbuhan terkonsentrasi. Strategi penetrasi mengarahkan sumber daya kepada pertumbuhan keuntungan dari produk tunggal, pasar tunggal dalam teknologi yang dominan (Hutabarat dan Martani, 2006).

\section{Metode}

Jenis penelitian ini adalah eksplanatori yang bermaksud menjelaskan kedudukan variabel - variabel yang diteliti serta hubungan antara suatu variabel dengan variabel yang lain, dan termasuk dalam penelitian asosiatif atau hubungan yang berfungsi untuk menjelaskan, meramalkan dan mengontrol suatu gejala (Sugiyono, 2011). Dalam penelitian ini penelitian eksplanatory digunakan untuk menjelaskan hubungan kasual antara variabel bebas dan terikat yang telah dirumuskan dalam hipotesis sebelumnya.

Populasi adalah wilayah generalisasi yang terdiri atas: obyek/ subyek yang mempunyai kualitas dan karakteristik tertentu yang ditetapkan oleh peneliti untuk dipelajari dan kemudian ditarik kesimpulannya (Sugiyono, 2004). Populasi dalam penelitian ini adalah perajin batik yang terdaftar sebagai anggota Klaster Batik di Kota Semarang, yaitu sebanyak 74 perajin (Data Disperindag Kota Semarang, 2017). Sementara itu, sampel ditetapkan sebanyak keseluruhan populasi. Teknik pengambilan sampel dalam penelitian ini menggunakan census sampling.

\section{Hasil dan Pembahasan}

Koefisien korelasi digunakan untuk mengetahui ada tidaknya hubungan antara 
variabel kualitas produk dengan variabel penetrasi pasar. Berdasarkan hasil uji korelasi yang dilakukan dengan menggunakan IBM SPSS 19.00 dapat diketahui bahwa hasil pengujian adalah sebesar 0,770. Artinya korelasi antara variabel kualitas produk dengan variabel penetrasi pasar sebesar 0,770. Berdasarkan tabel pedoman koefisien korelasi, maka koefisien korelasi 0,770 masuk kategori korelasi yang kuat. Jadi dapat dinyatakan terdapat hubungan yang positif variabel kualitas produk $\left(\mathrm{X}_{1}\right)$ dengan tingkat hubungan yang kuat terhadap penetrasi pasar (Y).

Koefisien determinasi digunakan untuk mengetahui presentase hubungan variabel kualitas produk terhadap penetrasi pasar menggunakan koefisien determinasi (Adjusted $R$ Square). Berdasarkan perhitungan di atas didapat koefisien determinasi sebesar 0,588 atau 58,8 persen. Hal ini berarti bahwa pengaruh yang di berikan variabel kualitas produk terhadap variabel penetrasi pasar sebesar 58,8 persen sedangkan sisanya sebesar 41,2 persen dapat di pengaruhi faktor lain selain faktor kualitas produk.

Berdasarkan perhitungan yang menggunakan program IBM SPSS 19, diketahui bahwa nilai $t$ hitung untuk uji hipotesis dari variabel kualitas produk $\left(\mathrm{X}_{1}\right)$ terhadap penetrasi pasar (Y) sebesar 10,246 dengan probabilitas kesalahan (signifikansi) sebesar 0,000. Berdasarkan tabel $\mathrm{t}$, diketahui bahwa $\mathrm{df}=\mathrm{n}-2$ atau $74-2=72$, sehingga $\mathrm{t}$ tabel untuk df $=72$ pada alpha sebesar $5 \%$ adalah sebesar 1,993. Oleh karena kualitas produk $\mathrm{t}$ hitung sebesar 10,246 dengan signifikansi sebesar $0,000<$ taraf signifikansi 0,05 maka inferensi yang dapat diambil adalah menerima hipotesis penelitian yang berbunyi "kualitas produk berpengaruh signifikan terhadap penetrasi pasar" dan menolak hipotesis nol (Ho) yaitu kualitas produk tidak berpengaruh signifikan terhadap penetrasi pasar.

Koefisien korelasi digunakan untuk mengetahui ada tidaknya hubungan antara variabel citra merk dengan variabel penetrasi pasar. Berdasarkan hasil uji korelasi yang dilakukan dengan menggunakan IBM SPSS
19 dapat diketahui bahwa hasil pengujian adalah sebesar 0,694.Artinya korelasi antara variabel citra merk dengan variabel penetrasi pasar sebesar 0,694. Berdasarkan tabel pedoman koefisien korelasi, maka koefisien korelasi 0,694 masuk kategori korelasi yang kuat. Jadi dapat dinyatakan terdapat hubungan yang positif variabel citra merk $\left(\mathrm{X}_{1}\right)$ dengan tingkat hubungan yang kuat terhadap penetrasi pasar $(\mathrm{Y})$.

Koefisien determinasi digunakan untuk mengetahui presentase hubungan variabel citra merk terhadap penetrasi pasar menggunakan koefisien determinasi (Adjusted $R$ Square). Berdasarkan perhitungan di atas didapat koefisien determinasi sebesar 0,474 atau 47,4 persen. Hal ini berarti bahwa pengaruh yang diberikan variabel citra merk terhadap variabel penetrasi pasar sebesar 47,4 persen sedangkan sisanya sebesar 52,6 persen dapat dipengaruhi faktor lain selain faktor citra merk, seperti citra merk, minat maupun rekomendasi.

Berdasarkan perhitungan yang menggunakan program IBM SPSS 19, diketahui bahwa nilai $\mathrm{t}$ hitung untuk uji hipotesis dari variabel citra merk $\left(\mathrm{X}_{2}\right)$ terhadap penetrasi pasar $(\mathrm{Y})$ sebesar 8,168 dengan probabilitas kesalahan (signifikansi) sebesar 0,000. Berdasarkan tabel $t$, diketahui bahwa $\mathrm{df}=\mathrm{n}-2$ atau $74-2=72$, sehingga $\mathrm{t}$ tabel untuk df $=72$ pada alpha sebesar $5 \%$ adalah sebesar 1,993 . Oleh karena citra merk $\mathrm{t}$ hitung sebesar 9,578 dengan signifikansi sebesar $0,000<$ taraf signifikansi 0,05 maka inferensi yang dapat diambil adalah menerima hipotesis penelitian yang berbunyi "citra merk berpengaruh signifikan terhadap penetrasi pasar" dan menolak hipotesis nol (Ho) yaitu citra merk tidak berpengaruh signifikan terhadap penetrasi pasar.

Koefisien korelasi digunakan untuk mengetahui ada tidaknya hubungan antara variabel kualitas produk, dan citra merk terhadap penetrasi pasar. Berdasarkan tabel rekapitulasi diketahui nilai $\mathrm{R}=0,801$ menunjukkan bahwa korelasi antara pelayanan dan citra merk terhadap penetrasi pasar adalah kuat. Artinya kualitas produk, 
dan citra merk memberi pengaruh yang kuat terhadap penetrasi pasar.

Koefisien determinasi akan menjelaskan seberapa besar perubahan atau variasi suatu variabel bisa dijelaskan oleh perubahan atau variasi pada variabel yang lain. Ini berarti bahwa koefisien determinasi digunakan untuk mengetahui seberapa besar sumbangan yang diberikan variabel kualitas produk, dan citra merk terhadap penetrasi pasar. Untuk mengetahui prosentase $(\%)$ hubungan antara kualitas produk, dan citra merk terhadap penetrasi pasar, dengan menggunakan koefisien determinasi (Adjusted R-Square), di mana diperoleh angka sebesar 0,631 (63,1 persen). Hal ini berarti pengaruh yang diberikan oleh variabel kualitas produk, dan citra merk terhadap penetrasi pasar adalah sebesar 63,1 persen sedangkan sisanya yaitu 36,9 persen dipengaruhi oleh variabel lain, selain kualitas produk, dan citra merk.

Pengaruh variabel kualitas produk $\left(\mathrm{X}_{1}\right)$ dan citra merk $\left(\mathrm{X}_{2}\right)$ terhadap variabel penetrasi pasar $(\mathrm{Y})$ maka dilakukan pengujian dengan menggunakan uji $\mathrm{F}$. Untuk menguji antara variabel kualitas produk $\left(\mathrm{X}_{1}\right)$ dan citra merk $\left(\mathrm{X}_{2}\right)$ secara bersama-sama (simultan) berpengaruh terhadap variabel penetrasi pasar (Y). Uji $\mathrm{F}$ ini dilakukan dengan membandingkan $\mathrm{F}$ hitung dengan $\mathrm{F}$ tabelnya. $\mathrm{F}$ hitung dapat diperoleh dengan memperhatikan uji $\mathrm{F}$ pada Tabel ANOVA, jumlah variabel bebas $(\mathrm{k})=2$ serta taraf signifikansi $\alpha=5 \%$, maka dapat diperoleh $\mathrm{dk}$ pembilang $\mathrm{k}=2$ dan df penyebut $=(\mathrm{n}-\mathrm{k}-1)$ $=(74-2-1)=71$, sehingga diperoleh $\mathrm{F}$ tabel $=3,13$.

Hasil perhitungan SPSS menunjukkan $\mathrm{F}$ hitung $>\mathrm{F}$ tabel yaitu $63,404>3,13$ dengan sig $0,000<0,05$. Dari perhitungan tersebut dapat di ambil kesimpulan bahwa Ho ditolak dan $\mathrm{Ha}$ diterima yang berarti bahwa ada pengaruh signifikan antara kualitas produk $\left(\mathrm{X}_{1}\right)$ dan citra merk $\left(\mathrm{X}_{2}\right)$ terhadap variabel penetrasi pasar (Y).

\section{Kesimpulan}

Berdasarkan analisis dan pengujian data serta pengujian hipotesis yang diajukan, maka dapat ditarik kesimpulan sebagai berikut: hasil pengujian dapat menerima hipotesis penelitian yang berbunyi kualitas produk berpengaruh signifikan terhadap penetrasi pasar. Sedangkan dari koefisien determinasinya, variabel kualitas produk berpengaruh terhadap variabel penetrasi pasar sebesar 58,8 persen. Hal ini juga dapat dilihat dari hasil dari koefisien korelasi yang termasuk kategori korelasi yang kuat. Selain itu berdasarkan regresi sederhana, terlihat bahwa pengaruh yang diberikan oleh kualitas produk terhadap variabel penetrasi pasar adalah positif atau jika penilaian responden terhadap kualitas produk menjadi baik maka juga akan mempengaruhi meningkatnya penetrasi pasar.

Berdasarkan uji hipotesis, terlihat bahwa hasil pengujian dapat menerima hipotesis penelitian yang berbunyi citra merk berpengaruh signifikan terhadap penetrasi pasar. Sedangkan dari koefisien determinasinya, variabel citra merk berpengaruh terhadap variabel penetrasi pasar sebesar 47,4 persen. Hal ini juga dapat dilihat dari hasil dari koefisien korelasi yang termasuk kategori korelasi yang kuat. Selain itu berdasarkan regresi sederhana, terlihat bahwa pengaruh yang diberikan oleh citra merk terhadap variabel penetrasi pasar adalah positif atau jika penilaian responden terhadap citra merk menjadi baik maka juga akan mempengaruhi meningkatnya penetrasi pasar.

Hubungan antara variabel kualitas produk dan citra merk dengan variabel penetrasi pasar secara bersama-sama dapat dirinci sebagai berikut. Kualitas produk dan citra merk secara bersama-sama berpengaruh positif terhadap penetrasi pasar. Hal ini dapat dilihat dari hasil dari koefisien korelasi yang termasuk kategori korelasi yang kuat. Selain itu berdasarkan regresi linier berganda, terlihat bahwa pengaruh yang diberikan oleh kualitas produk dan citra merk terhadap variabel penetrasi pasar adalah positif dimana jika penilaian terhadap variabel kualitas produk dan citra merk meningkat, maka akan meningkatkan penilaian penetrasi pasar.

Berdasarkan uji hipotesis $\mathrm{F}$, terlihat bahwa hasil pengujian dapat menerima hipotesis penelitian yang berbunyi ada 
pengaruh signifikan antara kualitas produk dan citra merk terhadap variabel penetrasi pasar. Sedangkan berdasarkan koefisien determinasinya, $63,1 \%$ penetrasi pasar dipengaruhi oleh produk dan promosi dan sisanya dipengaruhi oleh faktor lain.

\section{Saran}

Industri Kecil dan Menengah (IKM) Klaster Batik di Kota Semarang perlu meningkatkan jenis kain yang digunakan sehingga konsumen merasa nyaman dalam menggunakan batik corak Semarangan yang dijual oleh IKM Klaster Batik Kota Semarang. Selain itu Industri Kecil dan Menengah (IKM) Klaster Batik di Kota Semarang perlu mempertimbangkan penggunaan pewarna alami sehingga warna batik awet dan lebih cerah.

Industri Kecil dan Menengah (IKM) Klaster Batik di Kota Semarang perlu meningkatkan kekhasan corak Semarangan dengan menambahkan motif seperti Tugu Muda, Simpang Lima, Lawang Sewu, Sam Poo Kong yang merupakan landmark khas Kota Semarang sehingga mampu menarik perhatian lebih banyak konsumen. Selain itu IKM Klaster Batik Semarang juga perlu meningkatkan rasa kebanggaan konsumen dalam menggunakan batik Semarangan dan mempromosikan batik corak Semarangan melalui media sosial.

\section{Daftar Referensi}

Durianto, D., Sugiarto dan T. Sitinjak. (2004). Strategi Menaklukkan Pasar Melalui Riset Ekuitas dan Perilaku Merek. Jakarta. PT. Gramedia Pustaka Utama.

Effendi.(1996). Studi Perbedaan Biaya Kualitas Sebelum dan Sesudah Penerapan Quality Assurance System. Jurnal Ekobis Vol 4 No 3.

Ennew T. Christine, and Nigel Waite. (2007). Financial Services Marketing: An International Guide To Principles and Practice. USA: Elsevier Ltd.
Ghozali, Imam. (2011). Aplikasi Analisis Multivariate dengan Program IBM SPSS 19. Edisi 5. Semarang: Badan Penerbit Universitas Diponegoro.

Goetsch, David dan Stanley B. Davis. (2002). Pengantar Manajemen Mutu 2. Jakarta: Prenhalido.

Hill, C. W. L., dan Jones, G. R. (2008). Strategic Management An Integrated Approach. Mason, Ohio: South-Western Cengage Learning.

Hutabarat, Jemsly dan Husein, Martani. (2006). Operasionalisasi Strategi, PFI: Manajemen Strategik Kontemporer. Jakarta: PT. Alex Media Komputindo.

Juran, Joseph M. (2003). Quality Planning and Analysis. New York: McGraw-Hill.

Kertajaya, Hermawan. (2000). Memenangkan Persaingan dengan Segi Tiga Diferensiasi, Positioning dan Brand. Jakarta: PT. Gramedia Pustaka Utama.

Kotler, Philip. (2014). Manajemen Pemasaran. Jakarta: Erlangga.

Listiyani, Aprilia. (2011). Pengaruh Karakteristik Produk Terhadap Intensi Pembelian Produk Private Label Carrefour. JBI, Vol 3 No 2.

Nurainun, Heriyana dan Rasyimah. (2008). Analisis Industri Batik di Indonesia. Jurnal Fokus Ekonomi (FE), Vol. 7, No. 3, Hal. 124-135.

Poeradisastra, Teguh. (2005). Produk Lokal Citra Global. Majalah SWA: 15/XXI/21 Juli - 3 Agustus 2005.

Purnomo, Andry. (2011). Strategi Penetrasi Pasar UD. Raja Bintang Gajah Dalam Upaya Meningkatkan Penjualan Produk. Agora, Vol 5 No 4.

Rangkuti, Freddy. (2002). Riset Pemasaran. Jakarta: PT. Gramedia Pustaka Utama bekerjasama dengan Sekolah Tinggi Ekonomi IBII. 
Royan, Frans M. (2004), Marketing Selebriti "Selebriti dalam Iklan dan Strategi Selebriti Memasarkan Diri Sendiri". Jakarta: Alex Media Komputindo.

Sen, Subhasis dan Kannan Rajagopal. (2015). Market Penetration through Sales Promotion - A Review. The Economic Times Vol 7 No 2.
Solihin, Ismail. (2004). Kamus Pemasaran. Bandung: Penerbit Pustaka.

Sugiyono. (2013). Metode Penelitian Pendidikan: Kuantitatif, Kualitatif dan $R \& D$. Bandung: CV Alfabeta.

Swasta, Basu dan Irawan. (2010). Manajemen Pemasaran Modern. Edisi Keempat. Yogyakarta: Liberty. 